\title{
The Impact of Stocks Index Adjustments Announcement on Earnings Management
}

\author{
Chia-Jung Tu \\ Correspondence: Chia-Jung Tu, Department of Banking and Finance, Kainan University, No.1 Kainan Road, \\ Luzhu Shiang, Taoyuan 33857, Taiwan. Tel: 886-3-341-2500 ext. 7913. E-mail: cjtu@mail.knu.edu.tw
}

Received: September 8, 2012 Accepted: September 25, $2012 \quad$ Online Published: October 10, 2012

doi:10.5539/ijef.v4n11p91 URL: http://dx.doi.org/10.5539/ijef.v4n11p91

\begin{abstract}
This study considers the situation of Morgan Stanley Capital International (MSCI) Taiwan Index adjustment announcement to examine the behavior of manager earnings management during the period 1999-2010. Survey whether the changes by declaring, in turn convey the manager's use of discretionary accruals. It is to explore whether the manager earnings management degree is high (low) when firms deleted from (added to) MSCI Taiwan index. The empirical and analytical results show that the discretionary accrual changes degree of added firms is not significantly smaller than that of deleted firms and the result implies that there seems no information effect in MSCI Taiwan index adjustment announcement.
\end{abstract}

Keywords: earnings management, MSCI Taiwan index, adjustment announcement, discretionary accruals

\section{Introduction}

Since the end of 2001, the U.S. went through a succession of business crisis storm. Enron made the forged account, WorldCom hide the losses, AOL TIME Warner reported the false advertising revenue, Johnson \& Johnson was accused the concealment product error and other major events all caused investors' confidence falling, and investors had suffered huge losses, and the confidence of corporate financial reports were also a serious setback.

All events above, earnings management became an issue of high priority and a variety of accounting reforms were under consideration. When information asymmetry is high, stakeholders do not have sufficient resources, incentives, or access to relevant information to monitor manager's actions, which gives rise to the practice of earnings management (Schipper, 1989). Lobo and Zhou (2001) and Hunton, Libby and Mazza (2006) indicate that there is a statistically significant negative relationship between corporate disclosure and earnings management. Firms that disclose less tend to engage more in earnings management and vice versa. Jo and Kim (2007) supports the notion that greater disclosure frequency helps reduce information asymmetry, enhances the transparency of earnings, improves SEO pricing, and reduces post-issue SEO underperformance.

Therefore, this study investigates 130 added firms and 91 deletion firms during the period 1999- 2010 to explore whether the manager earnings management degree is high when firms deleted from MSCI Taiwan index and whether the manager earnings management degree is low when firms added to MSCI Taiwan index. Unlike some prior studies investigating firms' earnings management of S\&P 500, the analytical results show that the discretionary accrual changes degree of added firms is not significantly smaller than that of deleted firms and the result implies that there seems no information effect in MSCI Taiwan index adjustment announcement. This study is the first study to examine the relationship between MSCI Taiwan Index adjustments announcement and earnings management. Investors should find some information content embedded in the index adjustments announcement.

\section{Literature Review}

Earnings, sometimes called the "bottom line" or "net income," are the single most important item in financial statements. They indicate the extent to which a company has engaged in value-added activities. They are a signal that helps direct resource allocation in capital markets. In fact, the theoretical value of a company's stock is the present value of its future earnings. Increased earnings represent an increase in company value, while decreased earnings signal a decrease in that value (Lev, 1989). Given the importance of earnings, it is no surprise that company management has a vital interest in how they are reported. That is why every executive needs to 
understand the effect of their accounting choices so they can make the best possible decisions for the company. They must, in other words, learn to manage earnings (Note 1). News that a firm has fallen short of earnings expectations can immediately send its stock price plummeting; firms that beat expectations, on the other hand, are handsomely rewarded by investors (K. Chan, L. Chan, Jegadeesh, \& Lakonishok, 2006).

Watts and Zimmerman (1978) suggested that the managers might engage in different accounting policies to manipulate earnings of accounting and in turn affected cash flows. Healy (1985) considered that the managers would use the components of discretionary accruals to manipulate earnings. Schipper (1989) also found that the manager would use the discretionary accruals to control the result of earnings. Jones (1991) and Teoh, Welch and Wong (1998) noted the managers might adjust time and places of profit and loss to achieve earnings management purposes. In addition, McNichols (2000) indicated that accruals are positively related to analysts' forecasts of future earnings growth even after controlling for contemporaneous growth.

Bernstein and Siegel (1979) and Bricker, Previts, Robinson and Young (1995) found that the fluctuations of the net income would affect the earnings quality. The smaller the fluctuations of the net income, the better for analysts to predict the future net income, and the greater of earnings quality. Sloan (1996) documented an intriguing return anomaly associated with accruals. He found that companies with high accruals earned lower abnormal returns than companies with low accruals. Collins and Hribar (2000) confirm this finding with quarterly accruals. Beneish and Vargus (2002) analyzed accruals, insider trading, and subsequent earnings quality. They found that the stocks trading for internal parties would affect the earnings quality. Following internal parties' trading, changes in total accruals and current accruals occurred. Penman and Zhang (2002) found that earnings quality would be affected by changes in accounting principles and investment decisions, which further affected the returns of accounting. Chan et al. (2006) found that there is a reliable, negative association between accruals and future stock returns.

Jo and Kim (2007) examined the relation between disclosure frequency and earnings management, and the impact of this relation on post-issue performance, for a sample of seasoned equity offerings (SEOs). They found that disclosure frequency is inversely related to earnings management and positively associated with post-issue performance. Platikanova (2008) examined the relationship between earnings quality and the long-term price effect of addition to the S\&P 500. The trading-based explanations showed the positive abnormal returns following index addition. He also found that discretionary accruals significantly decrease is the conclusive cause, which greatly improves earnings quality. Chang and Sun (2010) investigate whether Sarbanes-Oxley Act (SOX)'s recently mandated disclosure of corporate governance structures affects the market's perception of earnings informativeness and firms' earnings management. They found that the quality of accounting earnings is increased after the SOX's mandated disclosure, which strengthens the link between financial reporting and corporate governance functions. Boon, Chan and Lee (2011) investigate whether Internet firms have a higher tendency to engage in earnings management than the brick-and-mortar firms. They use discretionary current accruals as the proxy for earnings management and find Internet firms have a greater tendency to manage their earnings.

Based on the foregoing literature review show when the companies have higher information transparency, the manager earnings management's behavior will be less. By the same token when the company is paid attention to by investors, the earnings management behavior is easier to be found, therefore the manager will reduce the motivation for earnings management. Otherwise, when the company is neglected by the investors, the manager will carry on more earnings management. Inference from here, this study predicts firms experience a lower earnings management degree on inclusion (addition to) in the MSCI Taiwan index and a higher earnings management degree on deletion from the MSCI Taiwan index. This leads to the following hypothesis:

\section{Hypothesis 1a:}

Compared to the deleted firm, the newly added firm its manager management degree is lower, discretionary accrual changes should reduce.

It also has the possibility that the added and deleted firms already have received investor's attention before index adjusted announcement. That means the investors will not reduce their attention because of company's situation change. Hence, company managers have been engaged in a very weak motivation for earnings management since then. Therefore, this leads to the following hypothesis:

\section{Hypothesis 1b:}

Compared to the deleted firm, the newly added firm its manager management degree is unchange, discretionary accrual changes have no markedly difference. 


\section{Research Methodology}

\subsection{Earnings Management Test Method}

There are many ways common used in manipulate the earnings management, including changes in accounting methods, changes in business operations, and adjusts the accruals. The accruals are easier to manipulate in practice and with lower cost. There are many scholars' research focus on the accruals, the results all show that for firms with higher level of accruals, the managers should be more likely to manipulate earnings. Healy (1985) and Schipper (1989) found that the managers would use the components of discretionary accruals to manipulate earnings. Therefore, this study uses discretionary accruals to measure earnings management.

The discretionary accruals will be estimated using the Modified Jones Model suggested by Dechow, Sloan and Sweeney (1995) as an improvement of the original Jones model (Jones, 1991). The model is as:

$$
\frac{T A_{i t}}{A_{i t-1}}=\alpha_{0}\left(\frac{1}{A_{i t-1}}\right)+\alpha_{1}\left(\frac{\Delta R E V_{i t}}{A_{i t-1}}\right)+\alpha_{2}\left(\frac{P P E_{i t}}{A_{i t-1}}\right)+\varepsilon_{i t}
$$

where

$T A_{i t}$ is the total accruals of firm $i$ in year $t$;

$A_{i t-1}$ is the total assets of firm $i$ at the end of year $t-1$;

$\triangle R E V_{i t}$ is the change in revenues of firm $i$ between years $t$ and $t-1$;

$P P E_{i t}$ is the gross property plant and equipment of firm $i$ in year $t$.

The parameters of Eq. (1) are estimated using ordinary least squares, and take them into Eq. (2) calculate the nondiscretionary accruals.

$$
N D A_{i t}=\hat{\alpha}_{0}\left(\frac{1}{A_{i t-1}}\right)+\hat{\alpha}_{1}\left(\frac{\Delta R E V_{i t}-\Delta R E C_{i t}}{A_{i t-1}}\right)+\hat{\alpha}_{2}\left(\frac{P P E_{i t}}{A_{i t-1}}\right)
$$

where $\triangle R E C_{i t}$ is the change in receivables of firm $i$ between years $t$ and $t-1$. Finally, discretionary accruals (DA) equal total accruals (TA) minus nondiscretionary accruals (NDA).

$$
D A_{i t}=\frac{T A_{i t}}{A_{i t-1}}-N D A_{i t}
$$

\subsection{Research Model Establishment}

This study is to explore whether the manager earnings management degree is high when firms deleted from MSCI Taiwan index and whether the manager earnings management degree is low when firms added to MSCI Taiwan index. It is to examine whether the discretionary accrual changes $(\triangle \mathrm{DA})$ degree of the added firms smaller than that of the deletion firms. This study adopts a dummy variable $\mathrm{INC}_{i t}$ to represent the added firms and the deletion firms. $\mathrm{INC}_{i t}$ is taking a value of 1 for firm $i$ adding to MSCI Taiwan index in year $t$ and 0 for firm $i$ deleting from MSCI Taiwan index in year $t$. Then, a multiple regression approach is used to identify the important factors that relate to discretionary accrual changes $(\triangle \mathrm{DA})$. The seven most commonly cited variables are firm size (SIZE), debt ratios (LEV), operating cash flow (OCF), absolute values of total accruals (ABSTA), return of asset (ROA), growth opportunity (GROWTH), and the discretionary accrual changes at $t-1\left(\triangle \mathrm{DA}_{t-1}\right)$. $\mathrm{OCF}$ and $\Delta \mathrm{DA}_{t-l}$ are hypothesized to have a negative relationship to the discretionary accruals change. ABSTA and ROA are hypothesized to have a positive relationship to the discretionary accruals change. Therefore, this study can set up a regression model as follow:

$$
\begin{aligned}
\Delta D A_{i t}= & \beta_{0}+\beta_{1} I N C_{i t}+\beta_{2} S I Z E_{i t}+\beta_{3} L E V_{i t}+\beta_{4} O C F_{i t}+\beta_{5} R O A_{i t}+ \\
& \beta_{6} G R O W T H_{i t}+\beta_{7} A B S T A_{i t}+\beta_{8} \Delta D A_{i t-1}
\end{aligned}
$$

$\Delta \mathrm{DA}_{i t}$ is the discretionary accrual changes of firm $i$ in year $t$ and equals $\mathrm{DA}_{\mathrm{t}}-\mathrm{DA}_{\mathrm{t}-1}$.

$\mathrm{INC}_{i t}$ is a dummy variable taking a value of 1 for firms $i$ adding to MSCI Taiwan index in year $t$ and 0 for firms $i$ deleting from MSCI Taiwan index in year $t$.

$\mathrm{SIZE}_{i t}$ is the natural logarithm of the total assets of firm $i$ in year $t$.

$\mathrm{LEV}_{i t}$ is the total debt to total assets ratio of firm $i$ in year $t$.

$\mathrm{OCF}_{i t}$ is the operating cash flow scaled by the total assets of firm $i$ in year $t$. 
$\mathrm{ROA}_{i t}$ is the return of asset of firm $i$ in year $t$.

GROWTH $_{i t}$ is the net sales change growth rate of firm $i$ in year $t$.

ABSTA $_{i t}$ is absolute values of total accruals of firm $i$ in year $t$.

$\Delta \mathrm{DA}_{i t-1}$ is the discretionary accrual changes of firm $i$ in year $t-1$ and equals $\mathrm{DA}_{t-1}-\mathrm{DA}_{t-2}$.

\subsection{Data Source}

This study uses stocks either added to or deleted from the MSCI Taiwan Index to examine the information effect during the periods from 1999 to 2010. Excluding finance and insurance industries and insufficient data firms during the event periods, the final samples comprised 130 firms added to and 91 firms deleted from the MSCI Taiwan Index. Table 1 summarizes the information of the sample. The firm-year observations with financial statements information are obtained from the TEJ (Taiwan Economic Journal). Furthermore, announcement date information for MSCI Taiwan Index adjustment is obtained from the UDN (United Daily News) data.

\section{Empirical Results Analysis}

\subsection{Descriptive Statistics and Univariate Analysis}

The descriptive statistics for the variables are shown in Table 2. The mean of discretionary accrual changes in year $t\left(\Delta \mathrm{DA}_{i t}\right)$ is -0.0087 (median=0.0001). The mean firm size $\left(\mathrm{SIZE}_{i t}\right)$ is 16.9237 (median=16.8878), and the mean debt ratios $\left(\mathrm{LEV}_{i t}\right)$ is 0.3876 (median=0.3950). Sample firms have a mean operating cash flow $\left(\mathrm{OCF}_{i t}\right)$ of $0.1016($ median $=0.0702)$, a mean net sales change growth rate $\left(\mathrm{GROWTH}_{i t}\right)$ of 0.1137 (median=0.0721), and a mean absolute values of total accruals $\left(\mathrm{ABSTA}_{i t}\right)$ of 0.0863 (median=0.0547). The ratio of return of asset $\left(\mathrm{ROA}_{i t}\right)$ ranges from $-62.39 \%$ to $53.1 \%$, with a mean (median) of $7.33 \%(6.32 \%)$. The mean of discretionary accrual changes in year $t-1\left(\Delta \mathrm{DA}_{i t-1}\right)$ is -0.0103 (median $\left.=-0.0064\right)$.

Table 3 presents the results of descriptive statistics and univariate analyses of firms adding to MSCI Taiwan index $\left(\mathrm{INC}_{i t}=1\right)$ and firms deleting from MSCI Taiwan index $\left(\mathrm{INC}_{i t}=0\right)$. The results indicate that the mean discretionary accrual changes in year $t$ of additions is 0.000 higher than that of deletions (mean $=-0.021$ ), but the $t$-test and Wilcoxon two-sample test are not significantly greater than $0(\mathrm{p}=0.255 ; \mathrm{p}=0.327)$. These results seem that the manager earnings management degree is no difference when firms added to or deleted from MSCI Taiwan index. The result tends to support hypothesis $1 \mathrm{~b}$ and shows MSCI Taiwan index adjustment is an information-free event. As for other variables, firm size $\left(\mathrm{SIZE}_{i t}\right)$, operating cash flow $\left(\mathrm{OCF}_{i t}\right)$, return of asset $\left(\mathrm{ROA}_{i t}\right)$ and net sales change growth rate $\left(\mathrm{GROWTH}_{i t}\right)$ for additions are significantly greater than those for deletions. The debt ratio $\left(\mathrm{LEV}_{i t}\right)$ for additions is significantly smaller than that for deletions. This can be seen added firms' size and financial condition are better than deleted firms.

Table 1. Changes in the MSCI Taiwan Index

\begin{tabular}{ccc}
\hline & MSCI Taiwan Index & \\
\hline Year & Additions & Deletions \\
\hline 1999 & 11 & 13 \\
2000 & 3 & 15 \\
2001 & 27 & 6 \\
2002 & 2 & 1 \\
2003 & 11 & 7 \\
2004 & 8 & 0 \\
2005 & 7 & 6 \\
2006 & 8 & 4 \\
2007 & 26 & 3 \\
2008 & 3 & 26 \\
2009 & 23 & 7 \\
2010 & 1 & 3 \\
\hline Total & 130 & 91 \\
\hline
\end{tabular}

This table describes the number of firms added to or deleted from the MSCI Taiwan Index from 1999 to 2010. Excluding finance and insurance industries and insufficient data firms, the final samples comprised 130 firms added to and 91 firms deleted from the MSCI Taiwan Index. 
Table 2. Descriptive statistics for the variables

\begin{tabular}{ccccccccc}
\hline Variables & Number & Mean & S.D. & Minimum & Q1 & Median & Q3 & Maximum \\
\hline$\Delta \mathrm{DA}_{i t}$ & 221 & -0.0087 & 0.1378 & -0.9080 & -0.0703 & 0.0001 & 0.0614 & 0.3828 \\
$\mathrm{INC}_{i t}$ & 221 & 0.5882 & 0.4933 & 0 & 0 & 1 & 1 & 1 \\
$\mathrm{SIZE}_{i t}$ & 221 & 16.9237 & 0.8926 & 14.8884 & 16.2568 & 16.8878 & 17.4446 & 19.9485 \\
$\mathrm{LEV}_{i t}$ & 221 & 0.3876 & 0.1665 & 0.0474 & 0.2694 & 0.3950 & 0.4900 & 1.1141 \\
$\mathrm{OCF}_{i t}$ & 221 & 0.1016 & 0.1226 & -0.1757 & 0.0250 & 0.0702 & 0.1562 & 0.5679 \\
$\mathrm{ROA}_{i t}$ & 221 & 7.3291 & 13.5194 & -62.39 & 1.35 & 6.32 & 14.92 & 53.1 \\
$\mathrm{GROWH}_{i t}$ & 221 & 0.1137 & 0.3495 & -0.8997 & -0.1052 & 0.0721 & 0.2811 & 1.5076 \\
$\mathrm{ABSTA}_{i t}$ & 221 & 0.0863 & 0.0882 & 0.0005 & 0.0258 & 0.0547 & 0.1205 & 0.4570 \\
$\Delta \mathrm{DA}_{i t-1}$ & 221 & -0.0103 & 0.1657 & -1.5166 & -0.0582 & -0.0064 & 0.0461 & 0.4584 \\
\hline
\end{tabular}

As shown in Table 2, $\Delta \mathrm{DA}_{i t}$ is the discretionary accrual changes of firm $i$ in year $t$ and equals $\mathrm{DA}_{\mathrm{t}}-\mathrm{DA}_{\mathrm{t}-1 .} . \mathrm{INC}_{i t}$ is a dummy variable taking a value of 1 for firms $i$ adding to MSCI Taiwan. index in year $t$ and 0 for firms $i$ deleting from MSCI Taiwan index in year $t$. SIZE $i t$ is the natural logarithm of the total assets of firm $i$ in year $t . \mathrm{LEV}_{i t}$ is the total debt to total assets ratio of firm $i$ in year $t . \mathrm{OCF}_{i t}$ is the operating cash flow scaled by the total assets of firm $i$ in year $t$. $\mathrm{ROA}_{i t}$ is the return of asset of firm $i$ in year $t$ (unit: \%). GROWTH $\mathrm{G}_{i t}$ is the net sales change growth rate of firm $i$ in year $t$. $\mathrm{ABSTA}_{i t}$ is absolute values of total accruals of firm $i$ in year $t . \Delta \mathrm{DA}_{i t-l}$ is the discretionary accrual changes of firm $i$ in year $t-1$ and equals $\mathrm{DA}_{t-1}-\mathrm{DA}_{t-2}$.

\subsection{Regression Results Analysis}

This study reports a Pearson correlation matrix in Table 4. If only alone observes the relationship between discretionary accrual changes in year $t(\Delta \mathrm{DA} i t)$ and added firms $\left(\mathrm{INC}_{i t}\right)$, and it shows no significant correlation. Results from the table indicates $\Delta \mathrm{DA}_{i t}$ is positively associated with return of asset $\left(\mathrm{ROA}_{i t}\right)$ and negative associated with operating cash flow $\left(\mathrm{OCF}_{i t}\right)$ and discretionary accrual changes of firm $i$ in year $t-1\left(\Delta \mathrm{DA}_{i t-1}\right)$. These results exhibit the higher return of asset, the discretionary accrual changes are also higher. The more operating cash flow, the discretionary accrual changes are lower. In addition, $\triangle \mathrm{DA}_{i t}$ has no significant correlation with firm size $\left(\mathrm{SIZE}_{i t}\right)$, debt ratios $\left(\mathrm{LEV}_{i t}\right)$, net sales change growth rate $\left(\mathrm{GROWTH}_{i t}\right)$ and absolute values of total accruals $\left(\mathrm{ABSTA}_{i t}\right)$. In the table the correlation coefficients are almost all less than 0.5 , indicating that among independent variables seem without higher correlations. If further testing VIF among the independent variables, all values are less than 10 . Therefore, this study of colinearity among independent variables should be little doubt.

The multiple-regression results are reported in Table 5. The regression results reveal that the additions $\left(\mathrm{INC}_{i t}\right)$ are slight negatively associated the discretionary accrual changes $\left(\Delta \mathrm{DA}_{i t}\right)$. The discretionary accrual changes degree of added firms is not significantly smaller than that of deleted firms. The results also tend to support hypothesis $1 \mathrm{~b}$ show MSCI Taiwan index adjustment is an information-free event. The result is consistent with Tu and Chang (2012) who find that there is no significant information effect from MSCI Taiwan Index additions. The effects of control variables, the firm size $\left(\mathrm{SIZE}_{i t}\right)$ and absolute values of total accruals $\left(\mathrm{ABSTA}_{i t}\right)$ are slightly positively related with the $\triangle \mathrm{DA}_{i t}$. The net sales change growth rate $\left(\mathrm{GROWTH}_{i t}\right)$ is slightly negatively related with the $\Delta \mathrm{DA}_{i t}$. The coefficient estimate of debt ratio $\left(\mathrm{LEV}_{i t}\right)$ is 0.120 and significantly positively related with the $\Delta \mathrm{DA}_{i t}$, with a t-statistic of 2.423. The positive effect is consistent with Duke and Hunt (1990). The discretionary accrual changes $\left(\Delta \mathrm{DA}_{i t}\right)$ are significantly positively associated with return on assets $\left(\mathrm{ROA}_{i t}\right)$. The coefficient estimate is 0.008 , with a t-statistic of 10.566 . This result is consistent with Dechow et al. (1995), Kasznik (1999) and McNichols (2000). The result also indicates that consistent with Dechow et al. (1995) and Becker, Defond, Jiambalvo and Subramanyam (1998) $\Delta \mathrm{DA}_{i t}$ is negatively associated with $\mathrm{OCF}_{i t}$, operating cash flow, with a coefficient of -0.636 and a t-statistic of -5.898 . 
Table 3. Univariate analysis

\begin{tabular}{|c|c|c|c|c|c|c|c|c|}
\hline \multirow[b]{3}{*}{ variables } & \multicolumn{3}{|c|}{ Additions } & \multicolumn{3}{|c|}{ Deletions } & \multirow{3}{*}{$\begin{array}{c}\text { t-test } \\
\text { difference } \\
\text { (p-value) }\end{array}$} & \multirow{3}{*}{$\begin{array}{c}\text { Wilcoxon test } \\
\text { Z-value } \\
\text { (p-value) }\end{array}$} \\
\hline & \multicolumn{3}{|c|}{$\mathrm{INC}=1$} & \multicolumn{3}{|c|}{$\mathrm{INC}=0$} & & \\
\hline & number & mean & S.D. & number & mean & S.D. & & \\
\hline$\Delta \mathrm{DA}_{i t}$ & 130 & 0.000 & 0.151 & 91 & -0.021 & 0.117 & $0.021(0.255)$ & $-0.980(0.327)$ \\
\hline $\mathrm{SIZE}_{i t}$ & 130 & 17.084 & 0.967 & 91 & 16.695 & 0.720 & $0.388(\mathbf{0 . 0 0 1})$ & $2.977(\mathbf{0 . 0 0 3})$ \\
\hline $\mathrm{LEV}_{i t}$ & 130 & 0.354 & 0.143 & 91 & 0.435 & 0.186 & $-0.081(\mathbf{0 . 0 0 0})$ & $-3.026(\mathbf{0 . 0 0 2})$ \\
\hline $\mathrm{OCF}_{i t}$ & 130 & 0.140 & 0.139 & 91 & 0.046 & 0.060 & $0.094(\mathbf{0 . 0 0 0})$ & $-5.976(0.000)$ \\
\hline $\mathrm{ROA}_{i t}$ & 130 & 12.813 & 11.681 & 91 & -0.505 & 12.071 & $13.317(\mathbf{0 . 0 0 0})$ & $-8.224(\mathbf{0 . 0 0 0})$ \\
\hline $\mathrm{GROWTH}_{i t}$ & 130 & 0.191 & 0.363 & 91 & 0.003 & 0.297 & $0.189(\mathbf{0 . 0 0 0})$ & $-4.150(\mathbf{0 . 0 0 0})$ \\
\hline $\mathrm{ABSTA}_{i t}$ & 130 & 0.092 & 0.090 & 91 & 0.078 & 0.085 & $0.015(0.228)$ & $-1.555(0.120)$ \\
\hline$\Delta \mathrm{DA}_{i t-1}$ & 130 & -0.010 & 0.195 & 91 & -0.010 & 0.112 & $0.000(0.989)$ & $-0.739(0.460)$ \\
\hline
\end{tabular}

The variable definitions are the same with Table 2.

Table 4. Pearson Correlation Coefficients

\begin{tabular}{|c|c|c|c|c|c|c|c|c|c|}
\hline & $\Delta \mathrm{DA}_{i t}$ & $\mathrm{INC}_{i t}$ & SIZE $_{i t}$ & $\mathrm{LEV}_{i t}$ & $\mathrm{OCF}_{i t}$ & $\mathrm{ROA}_{i t}$ & GROWTH $_{i t}$ & $\mathrm{ABSTA}_{i t}$ & $\Delta \mathrm{DA}_{i t-1}$ \\
\hline \multirow[t]{2}{*}{$\Delta \mathrm{DA}_{i t}$} & 1 & & & & & & & & \\
\hline & . & & & & & & & & \\
\hline \multirow[t]{2}{*}{$\mathrm{INC}_{i t}$} & 0.077 & 1 & & & & & & & \\
\hline & $(0.255)$ & . & & & & & & & \\
\hline \multirow[t]{2}{*}{$\mathrm{SIZE}_{i t}$} & -0.028 & 0.215 & 1 & & & & & & \\
\hline & $(0.680)$ & $(0.001)$ & . & & & & & & \\
\hline \multirow[t]{2}{*}{$\mathrm{LEV}_{i t}$} & 0.000 & -0.240 & 0.319 & 1 & & & & & \\
\hline & $(0.996)$ & $(0.000)$ & $(0.000)$ & . & & & & & \\
\hline \multirow[t]{2}{*}{$\mathrm{OCF}_{i t}$} & -0.125 & 0.379 & -0.067 & -0.347 & 1 & & & & \\
\hline & $(0.063)$ & $(0.000)$ & $(0.322)$ & $(0.000)$ & . & & & & \\
\hline \multirow[t]{2}{*}{$\mathrm{ROA}_{i t}$} & 0.282 & 0.486 & -0.159 & -0.485 & 0.608 & 1 & & & \\
\hline & $(0.000)$ & $(0.000)$ & $(0.018)$ & $(0.000)$ & $(0.000)$ & . & & & \\
\hline \multirow[t]{2}{*}{ GROWTH $_{i t}$} & 0.053 & 0.267 & 0.114 & -0.094 & 0.277 & 0.394 & 1 & & \\
\hline & $(0.431)$ & $(0.000)$ & $(0.092)$ & $(0.163)$ & $(0.000)$ & $(0.000)$ & . & & \\
\hline \multirow[t]{2}{*}{$\mathrm{ABSTA}_{i t}$} & -0.008 & 0.081 & 0.094 & 0.106 & -0.166 & -0.163 & 0.025 & 1 & \\
\hline & $(0.909)$ & $(0.228)$ & $(0.163)$ & $(0.115)$ & $(0.014)$ & $(0.016)$ & $(0.716)$ & . & \\
\hline \multirow[t]{2}{*}{$\Delta \mathrm{DA}_{i t-l}$} & -0.420 & 0.001 & 0.022 & -0.018 & -0.092 & 0.078 & 0.072 & 0.014 & 1 \\
\hline & $(0.000)$ & $(0.989)$ & $(0.745)$ & $(0.785)$ & $(0.171)$ & $(0.249)$ & $(0.287)$ & $(0.841)$ & . \\
\hline
\end{tabular}

Figures in brackets are p-values (two-tailed). The variable definitions are the same with Table 2.

Table 5. Regression analysis result

\begin{tabular}{ccccc}
\hline Variables & Coefficient & Standard deviation & t-value & VIF \\
\hline Constant & -0.153 & 0.138 & -1.109 & \\
$\mathrm{INC}_{i t}$ & -0.016 & 0.014 & -1.167 & 1.571 \\
SIZE $_{i t}$ & 0.006 & 0.008 & 0.752 & 1.303 \\
LEV $_{i t}$ & 0.120 & 0.049 & $2.423^{* *}$ & 1.454 \\
OCF $_{i t}$ & -0.636 & 0.108 & $-5.898^{* * *}$ & 1.695 \\
$\mathrm{ROA}_{i t}$ & 0.008 & 0.001 & $10.566^{* * *}$ & 2.415 \\
$\mathrm{GROWTH}_{i t}$ & -0.016 & 0.025 & -0.621 & 1.253 \\
$\mathrm{ABSTA}_{i t}$ & 0.032 & 0.086 & 0.377 & 1.086 \\
$\Delta \mathrm{DA}_{i t-1}$ & -0.440 & 0.089 & $-4.927^{* * *}$ & 1.045 \\
\hline
\end{tabular}

F value $27.40 * * *$

Adjusted R-square $\quad 0.4898$

$$
\begin{aligned}
\mathrm{N}=221 & \\
\Delta D A_{i t}= & \beta_{0}+\beta_{1} I N C_{i t}+\beta_{2} S I Z E_{i t}+\beta_{3} L E V_{i t}+\beta_{4} O C F_{i t}+\beta_{5} R O A_{i t}+ \\
& \beta_{6} G R O W T H_{i t}+\beta_{7} \text { ABSTA }_{i t}+\beta_{8} \Delta D A_{i t-1}
\end{aligned}
$$

The variable definitions are the same with Table 2. $\quad * * *$ : significant at $1 \%$ level, **: significant at $5 \%$ Level, *: significant at $10 \%$ level. 


\section{Conclusions}

This study investigates 130 added firms and 91 deletion firms during the period 1999- 2010 to explore whether the manager earnings management degree is high when firms deleted from MSCI Taiwan index and whether the manager earnings management degree is low when firms added to MSCI Taiwan index. Unlike some prior studies investigating firms' earnings management of S\&P 500, the analytical results show that the discretionary accrual changes degree of added firms is not significantly smaller than that of deleted firms and the result implies that there seems no information effect in MSCI Taiwan index adjustment announcement. This study regresses the discretionary accrual changes $(\triangle \mathrm{DA})$ on some variable to identify the factors that drive firms' earnings management changes. The regression analysis reveals that return of asset (ROA), operating cash flow $(\mathrm{OCF})$ and debt ratios (LEV) are the major determinants for earnings management changes. It is the first study to examine the relationship between MSCI Taiwan Index adjustments announcement and earnings management. Investors should find some information content embedded in the index adjustments announcement.

\section{References}

Becker, C. L., Defond, M. L., Jiambalvo J., \& Subramanyam K. R. (1998). The Effect of Auditor Quality on Earnings Management. Contemporary Accounting Research, 15, 1-24. http://dx.doi.org/10.1111/j.1911-3846.1998.tb00547.x

Beneish, M. D., \& Vargus, M. E. (2002). Insider Trading, Earnings Quality and Accrual Mispricing, The Accounting Review, 77, 755-791. http://dx.doi.org/10.2308/accr.2002.77.4.755

Bernstein, L. A., \& Siegel, J. G. (1979). The Concept of Earnings Quality. Financial Analysts Journal 35, 72-75.

Boon, L., Chan, L., \& Lee, B. S. L. (2011). Earnings Management for Internet-stock Related Companies. Working paper. Nanyang Technological University

Bricker, R., Previts, G., Robinson, T., \& Young, S. (1995). Financial Analyst Assessment of Company Earning Quality. Journal of Accounting Auditing \& Finance, 19, 541-554. http://dx.doi.org/10.1177/0148558X9501000307

Chan, K., Chan, L. K. C., Jegadeesh, N., \& Lakonishok, J. (2006). Earnings Quality and Stock Returns. Journal of Business, 79, 1041-1082. http://dx.doi.org/10.1086/500669

Chang, J. C., \& Sun, H. L. (2010). Does the Disclosure of Corporate Governance Structures Affect Firms' Earnings Quality? Review of Accounting and Finance, 9, 212-243. http://dx.doi.org/10.1108/14757701011068048

Collins, D. W., \& Hribar, P. (2000). Earnings-based and Accrual-based Market Anomalies:One effect or Two? Journal of Accounting and Economics, 29, 101-123. http://dx.doi.org/10.1016/S0165-4101(00)00015-X

Dechow, P. M., Sloan, R. G., \& Sweeney, A. P. (1995). Detecting Earnings Management. The Accounting Review, 70, 193-225.

Duke, J. C., \& Hunt, H. G. (1990). An Empirical Examination of Debt Covenant Restrictions and Accounting-related Debt Proxies. Journal of Accounting and Economics, 12, 45-63. http://dx.doi.org/10.1016/0165-4101(90)90041-2

Healy, P. M. (1985). The Effect of Bonus Schemes on Accounting Decisions. Journal of Accounting and Economics, 7, 85-107. http://dx.doi.org/10.1016/0165-4101(85)90029-1

Hunton, J. E., Libby, R., \& Mazza, C. L. (2006). Financial Reporting Transparency and Earnings Management. The Accounting Review, 81, 135-157. http://dx.doi.org/10.2308/accr.2006.81.1.135

Lev, B. (1989). On the Usefulness of Earnings and Earnings Research: Lessons and Directions from Two Decades of Empirical Research. Journal of Accounting Research, 27, 153-192.

Lobo, G. J., \& Zhou, J. (2001). Disclosure Quality and Earnings Management. Asia-Pacific Journal of Accounting \& Economics, 8, 1-20. http://dx.doi.org/10.1080/16081625.2001.10510584

Jo, H., \& Kim, Y. (2007). Disclosure frequency and earnings management. Journal of Financial Economics, 84, 561-590. http://dx.doi.org/10.1016/j.jfineco.2006.03.007

Jones, J. J. (1991). Earnings Management During Import Relief Investigations. Journal of Accounting Research, 29, 193-228. http://dx.doi.org/10.2307/2491047

Kasznik, R. (1999). On the association between voluntary disclosure and earnings management. Journal of Accounting Research, 37, 57-81. 
McNichols, M. F. (2000). Research Design Issues in Earnings Management Studies. Journal of Accounting and Public Policy, 19, 313-345. http://dx.doi.org/10.1016/S0278-4254(00)00018-1

Penman, S. H., \& Zhang, X. J. (2002). Accounting Conservatism, the Quality of Earnings, and Stock Returns. The Accounting Review, 77, 237-264. http://dx.doi.org/10.2308/accr.2002.77.2.237

Platikanova, P. (2008). Long-Term Price Effect of S\&P 500 Addition and Earnings Quality. Financial Analysts Journal, 64, 62-76.

Schipper, K. (1989). Commentary on Earning Management. Accounting Horizons 3, 91-102.

Sloan, R. G. (1996). Do Stock Prices Fully Reflect Information in Accruals and Cash Flows about Future Earnings? The Accounting Review, 71, 289-316.

Teoh, S. H., Welch, I., \& Wong, T. J. (1998). Earnings Management and the Long-run Market Performance of Iinitial Public Offerings. Journal of Finance, 53, 1935-1974. http://dx.doi.org/ 10.1111/0022-1082.00079

Tu, C. J., \& Chang, Y. J. (2012). Analyst Responses to Stock-Index Adjustments: Evidence from MSCI Taiwan Index Additions. Review of Financial Economics, 21, 82-89. http://dx.doi.org/10.1016/j.rfe.2012.03.004

Watts, R., \& Zimmerman, J. (1978). Towards a Positive Theory of the Determination of Accounting Standards. The Accounting Review, 53, 112-134.

Note

Note 1. Data retrieved from http://www.swlearning.com/pdfs/chapter/0324223250_1.PDF 